\title{
The Effects of Using Garlic Extract for Quail Hatching Egg Disinfection on Hatching Results and Performance
}

\section{-Author(s)}

\section{Baylan $\mathrm{M}^{\prime}$ \\ Akpınar GC" \\ Canogullari SD"II \\ Ayasan Tiv}

Çukurova University, Faculty of Agriculture, Department of Animal Science, Adana/ TURKEY.

" Mustafa Kemal University, Faculty of Agriculture, Department of Animal Science, Hatay/TURKEY.

III Ömer Halisdemir University, Faculty of Agricultural Science and Technologies, Animal Production and Technologies Department, Niğde/TURKEY

Iv East Mediterranean Agricultural Research Institute, Adana/TURKEY.

\section{Mail Address}

Corresponding author e-mail address Mikail Baylan

University of Çukurova Faculty of Agriculture, Department of Animal

Science, 01330, Adana/TURKEY.

Tel: $\quad$ +90 5064079879

Email: mikailbaylan@gmail.com

\section{aKeywords}

Quail, hatching eggs, disinfection, garlic extract.

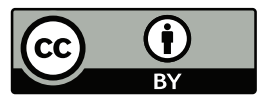

Submitted: 22/November/2017 Approved: 21/December/2017

\section{ABSTRACT}

This experiment was carried out to determine the effects of using garlic extract (Allium sativum) as an alternative to formaldehyde for the disinfection of hatching eggs on hatching traits and growth performance of quails. Four treatments, with 240 hatching eggs each, were evaluated: egg immersion in two different levels (2.5\% and 5.0\%) of garlic extract (garlic-1, garlic-2), formaldehyde fumigation (positive control), and eggs not submitted to disinfection (negative control). Mid-term and late embryomortality, pipped egg, and culled chick rates were not influenced by the $(p>0.05)$. The highest $(p<0.05)$ early embryo mortality rate was detected in the formaldehyde treatment $(9.99 \%)$, and the lowest in garlic-2 treatment (2.68\%). Hatchability of fertile eggs was the lowest in the formaldehyde group (83.78\%), followed by the control (85.20\%), garlic-1 (87.11\%) and garlic-2 $(88.72 \%)$ groups, respectively. The highest final body weight (5 weeks of age) was obtained in the garlic-2 group (304.1 g), followed by the control (294.13 g), formaldehyde (290.56 g), and garlic-1 (288.44 g), respectively, and the differences were statistically significant $(p<0.05)$. Feed intake and feed conversion ratio were not influenced by the treatments $(p>0.05)$. The results obtained for hatching traits and live performance parameters indicated that the immersion of eggs in garlic extract may be used as an alternative to formaldehyde fumigation for the disinfection of hatching quail eggs.

\section{INTRODUCTION}

In hatching eggs, microbial infections reduce hatchability and chick quality. Infection spreads in the hatchery and causes deaths in newlyhatched chicks due to omphalitis and yolk-sac infections (Pienaar et al., 1995). Egg infection depends on pre- and post-laying conditions. Eggs are usually infected when microorganisms enter through the digestive tract of the hen, and are transferred to the blood, contaminating the oviduct, and consequently infecting the egg yolk (Gordon \& Tucker, 1965). Several various microorganisms (Streptococcus spp. and coliaerogenes bacteria) may infect the oviduct during artificial insemination (Harry, 1963), due to the contact of the cloaca with the nesting box or litter material during oviposition (Harry, 1963; Board, 1964; Williams et al., 1968) or, most frequently, the microorganisms enter the egg through the eggshell pores (Cadirci, 1997).

In order to achieve high hatchability and to produce good-quality chicks, an effective hatching sanitation program is essential. The use of pre-hatching fumigation in breeding facilities and hatcheries aims at preventing the growth and reducing the numbers of microorganisms such as Salmonella, Escherichia coli, enterobacteria, molds, and yeasts on the eggshell surface (De Reu et al., 2006). 
Formaldehyde is typically used as a disinfectant of hatching eggs, but other chemicals, as hydrogen peroxide (Cox et al., 2000), Virkon S (GholamiAhangaran et al., 2016), propionic acid (Ibrahim et al., 2014), and quaternary ammonium (Arhienowa et al., 1980; Sacco et al.,1989) have been tested. Studies also report other methods for hatching egg disinfection, including ultraviolet light (Coufal et al., 2003; Al-Shammari et al., 2015), electrolyzed oxidizing water (Russell, 2003; Bialka et al., 2004; Keita et al., 2016), application of low and high frequency ultrasound (Yildirimet al., 2015; Aygun \& Sert, 2012; Al-Shammari et al, 2015), ozone (Hrcncar et al., 2012), and glutaraldehyde surfactant solution (Proudfoot et al., 1985). Natural products have been tested as alternatives to the use of formaldehyde, such as etheric thyme oil (Origanum vulgare), which has antimicrobial properties (Yildirim et al., 2003; Baydar et al., 2004; Copur et al., 2010; Debes \& Basyony, 2011), propolis (Aygun et al., 2013) and allicin (Copur et al., 2011).

Formaldehyde fumigation (FF) is an effective procedure for reducing the microbial contamination on the eggshell surface before hatching (Cadirci, 1997). However, it causes eyes and nose irritation, and has a pungent smell (Whistler \& Sheldon, 1989). Due to the possible carcinogenic effects of formaldehyde fumigation, health protection agencies have recently carried out studies and the use of FF is being reconsidered according under Toxic Materials Control Act (C\&EN, 1984).

Due to the growing demands for healthy and safe foods for human consumption in recent years, there has been a shift in the animal industry from synthetic compounds to natural and safer medicinal and aromatic plants. It was determined that active ingredients found in these plants have antibacterial, antifungal and antiviral effects. As a result, the number of studies on the use of natural products instead of synthetic materials for the disinfection of hatching eggs has increased (Copur et al., 2010; Copur et al., 2011; Aygun et al., 2012; Aygun \& Sert, 2012)

Studies performed to determine the antibiotic effects of garlic have focused on the use of unprocessed garlic, garlic extract, or on its active ingredient, allicin, as tablets. Garlic contains two powerful antibiotics: allicin and garlicin (Makaklı, 1980), which have antibacterial actions against Gram-positive and Gram-negative bacteria (Farbman et al., 1993). The antibacterial properties of garlic against Helicobacter pylori have been established invitro (Salih \& Abasıyanık, 2003). In the study of Astal \& Younis (2003), garlic (Allium sativum) extract at a concentration of $750-1000 \mu \mathrm{g} /$ $\mathrm{mL}$ showed very high antibacterial effect against Gram-positive bacteria, such as Staphylococcus aureus, Staphylococcus saprophyticus, Streptococcus pneumonia and Streptococcus faecalis, as well as against Gram-negative bacteria, including Escherichia coli, Enterobacter cloacae, Klebsiella pneumonia, Proteus mirabilis, Pseudomonas aeruginosa and Acinetobacter haemolyticus.

In studies on garlic powder supplementation in poultry feeds, the effects of garlic on cholesterol levels in the egg yolk (Lim et al, 2006), plasma, and meat (breast and leg) and the level of microbial fermentation in the gastrointestinal tract (Choi et al, 2010) were studied. In broilers, the effects of garlic on the levels of lead in chicken tissues (Hanafy et al., 1994), live weight (Al Homidan, 2005), performance and carcass traits (Raeesi et al., 2010) were evaluated. In addition, in broilers, the effects of garlic on enteropathogen counts, ileal histological structure, and productive parameters (Peinado et al., 2012), antioxidant characteristics (Jakubcova et al, 2014) and ascites incidence (Varmaghany et al., 2015) were studied. In turkeys, the effects on the parasitic disease histomoniasis (infectious enterohepatitis caused by Histomonas meleagridis) were evaluated by Hafez \& Hauck (2006). In layers and quails, the effects of dietary garlic addition on egg weight, feed intake, feed conversion ratio, body weight gain, serum and egg yolk cholesterol levels and egg productivity (Chowdhury et al., 2002 in layers; Yalcin et al., 2006 in layers; Yalcin et al., 2007 in quails; Ao et al., 2010 in layers; Canogullari et al, 2010 in quails), as well as on fecal bacterial load and on egg quality (Olobatoke \& Mulugeta, 2011) were studied.

The objective of this study was to determine if garlic, due to its antibacterial, antifungal, antiparasitic, and antiviral properties, can be used as an alternative to formaldehyde fumigation for the disinfection of hatching eggs.

\section{MATERIALS AND METHODS}

The hatching eggs used in the present study derived from the breeder quail flock of the Mustafa Kemal University, Samandag Vocational College Quail Unit.

In this study, 960 hatching eggs were randomly divided in four treatments groups (240 each): control group (negative control), which eggs were not submitted to any disinfection procedure; formaldehyde fumigation group (positive control), which eggs were disinfected by formaldehyde fumigation, and two 
garlic-extract groups, garlic-1 and garlic-2, which eggs were disinfected with $2.5 \%$ and $5.0 \%$ garlic, respectively. Each treatment group was consisted of four replicates with 60 eggs each. Trial coincidence parcels were executed as per the trial pattern (60x4x4=960 eggs, 60 eggs per tray, 4 replicates per treatment, 4treatments).

\section{Storage of hatching eggs}

Hatching eggs were collected daily from the quail farm, and those that were not cracked, broken, or contaminated with fecal matter or litter were brought on the same day to the trial location, where they were stored for 7 days at $75 \%$ relative humidity and 16 $18^{\circ} \mathrm{C}$ temperature.

\section{Treatment of hatching eggs with garlic extract and formaldehyde}

After 7 days of storage, eggs were immersed in garlic extract. The treatment of eggs with the garlic extract was performed using the dipping method. Hatching eggs were immersed in the extract for one minute, then left to dry for one minute at room temperature $\left(25^{\circ} \mathrm{C}\right)$. The amount of active ingredient per egg and/ or per 100 eggs was calculated to determine the standard solutions of 2.5 and $5 \%$ of garlic extract. Eggs were than immersed in $2 \mathrm{~L}$ of the mixture containing different doses of garlic extract (2.5\% and 5.0\%)

Eggs of the formaldehyde fumigation group (positive control) were fumigated for 20 minutes with the standard dose $(79.86 \mathrm{~mL}$ formalin and $39.93 \mathrm{mg}$ potassium per manganate $/ 2 \mathrm{~m}^{3}$ ) or $2 \mathrm{X}$ the standard dose (USDA, 1985).

\section{Hatching process}

After disinfection, egg groups were transported to the hatchery unit. Each replicate of 60 eggs (four per replicate) were placed in egg trays. Each tray was placed into the two separate setters (garlic groups in one setter and formaldehyde and negative-control groups in another setter). Setter temperature and relative humidity were kept at $37.5^{\circ} \mathrm{C}$ and $55-60 \%$, respectively, and $37.0^{\circ} \mathrm{C}$ and $70-80 \%$ in the hatcher.

\section{Post-hatching processes}

After incubation eggs were weighed to determine egg weight loss. Non-hatched eggs were counted to determine fertility rate (\%)and hatchability rates (\%) and broken to classify embryo mortality as early (0-6 days; black-eye and beak visible), mid-term (6 to 17 days; embryo with feathers, and with yolk out), or late (17 to 18 days; fully grown, with internalized yolk, and pipped eggs) mortality. The following formulas were used:

- Fertility rate: (number of fertilized eggs/number of eggs set) $\times 100$

- Egg weight loss: [(initial egg weight - egg weight measured on transfer day)/initial egg weight] $\times 100$

- Hatchability of set eggs: (number of hatched chicks /total number of eggs set) $\times 100$

- Hatchability of fertile eggs (\%): (number of hatched chicks /number of fertilized eggs set) x100

- Early embryo mortality: (number of dead embryos on days 0-6 of incubation/number of fertilized eggs) $\times 100$

- Mid-termembryo mortality: (number of dead embryos on days 7-18 of incubation/number of fertilized eggs) $\times 100$

- Late embryo mortality: (number of dead embryos on 19-21 days of incubation/number of fertilized eggs) $\times 100$

- Culled chick rate: (number of culled chicks/ number of saleable chicks) $\times 100$

- Contamination rate: (number of contaminated eggs/total number of eggs set) $\times 100$

\section{Growth Performance}

After the incubation period was completed, the chicks from each treatment group were weighed (between 144-161 chicks per treatment group), and chicks in each treatment group were divided in three replicates and housed in cages equipped with autoheated brooder for the first two weeks, and then transferred to 5 -tiered $20 \times 50 \times 100 \mathrm{~cm}$ cages (three replicates of 50 chicks each per treatment), where they were kept until the end of the $5^{\text {th }}$ week of age. A lighting program of 24-h of natural+artificial light was applied. Quails were fed a commercial broiler chick feed, with $22 \%$ crude protein and $3000 \mathrm{kcal} / \mathrm{kg} \mathrm{ME}$. Feed and water were provided ad libitum.

During the experiment, feed intake was measured once weekly per replicate, and body weight was measured once weekly per individual bird. Weekly feed intake and body weight gain were used to calculate feed conversion ratio. Weight measurements were taken using a scale sensitive to $0.1 \mathrm{~g}$.

\section{Statistical Analysis}

Statistical analysis of the experimental data was performed using the software package SPSS (one- 
The Effects of Using Garlic Extract for Quail Hatching Egg Disinfection on Hatching Results and Performance way analysis of variance) (SPSS, release 18). Duncan multiple comparison test was applied to compare differences among treatments.

\section{RESULTS AND DISCUSSION}

The results of the effects of garlic extract use for hatching egg disinfection on early, mid-term and late embryo mortality, culled chick rate, contamination rate, and hatching parameters are given in Table 1.

The highest early embryo mortality rate was observed in the formaldehyde group (9.99\%), and the lowest in the garlic-2 group $(2.68 \%)(p<0.05)$. Mid-term and late embryo mortality rates were not statistically different ( $p>0.05)$ among treatments. Mid-term embryo mortality rates in the control, formaldehyde, garlic 1 and garlic 2 groups were $0.52 \%, 0.40 \%, 1.44 \%$ and $1.59 \%$, respectively and late embryo mortality were $3.37 \%, 4.88 \%, 3.70 \%$ and $4.38 \%$, respectively. The higher early embryo mortality in the eggs disinfected by formaldehyde fumigation compared with other groups may be attributed to the possible damage of the egg cuticle layer by formaldehyde. Formaldehyde is an effective antimicrobial compound that reduces the microbial load on the eggshell surface. However, it also has a toxic effect (Cadirci, 1997). The lower early embryo mortality rate in the garlic-1 and garlic-2 groups compared with the control group, which was not submitted to any disinfection process, may be due to the reduction of the microbial load on the eggshell surface by garlic. In fact, Ankri \& Miralman (1999) reported that the active ingredient of garlic, allicin, is effective against many Gram-positive and Gramnegative bacteria, including Escherichia coli, and also has antifungal and antiviral activities. Similarly, Copur et al. (2011) reported that the use of allicin for the disinfection of hatching broiler eggs reduced the microbial load on the eggshell surface, consequently reducing early and late embryo mortality and improving hatchability.

The lowest culled chick rate was found in the formaldehyde group, with $0.52 \%$, followed by garlic-2 $(0.55 \%)$, garlic-1 $(0.94 \%)$, and control $(1.95 \%)$ groups; however, these differences were not statistically significant ( $p>0.05)$.

Among hatching parameters, hatchability of the control, formaldehyde, garlic-1 and garlic-2 groups were $79.46 \%, 75.11 \%, 76.44 \%$, and $76.32 \%$, respectively, and not statistically different $(p>0.05)$. The better hatching performance observed in the control group compared with the other groups may be related to its higher fertility rate $(p<0.05)$. The fertility rates of the control, formaldehyde, garlic 1 and garlic 2 treatments were $93.24 \%, 89.62 \%, 87.78 \%$ and $86.08 \%$ respectively.

The hatchability of fertile eggs was not statistically different ( $p>0.05)$ among treatments, with the lowest values determined in the formaldehyde group $(83.78 \%)$, followed by the control $(85.20 \%)$, garlic-1 $(87.11 \%)$, and garlic-2 (88.72\%). The numerically lower hatchability of fertile eggs obtained in the formaldehyde group may be explained with the higher early embryo mortality $(p<0.05)$ observed in this group. This result supports the findings of Elibol et al. (2003), who observed that the use of a high concentration (4X; $1 \mathrm{~m}^{3}-56 \mathrm{~mL}$ formalin+28g $\mathrm{KMnO}_{4}$ ) for the disinfection of chicken eggs reduced the hatchability of fertile eggs, which suggests that using formaldehyde for the disinfection of hatching eggs may have toxic effects on the embryos during incubation, increasing early stage mortality rates. However, our results are different from those obtained by Copur et al. (2010), who found that disinfecting chicken eggs with origanum etheric oil caused higher early and late embryo mortality compared with formaldehyde fumigation.

Table 1 - Hatching parameters according to treatmentgroups.

\begin{tabular}{|c|c|c|c|c|c|c|}
\hline \multirow{2}{*}{ Parameters } & & \multicolumn{4}{|c|}{ Groups } & \multirow[t]{2}{*}{ SEM } \\
\hline & & Control & Formaldehyde & Garlic 1 & Garlic 2 & \\
\hline \multicolumn{2}{|l|}{ Fertility rate (\%) } & $93.24^{a}$ & $89.62^{\mathrm{ab}}$ & $87.78^{\mathrm{ab}}$ & $86.08^{b}$ & 1.13 \\
\hline \multicolumn{2}{|l|}{ Hatchability of set eggs(\%) } & 79.46 & 75.11 & 76.44 & 76.32 & 1.15 \\
\hline \multicolumn{2}{|c|}{ Hatchability of fertile eggs (\%) } & 85.20 & 83.78 & 87.11 & 88.72 & 1.03 \\
\hline \multirow{3}{*}{ Embryonic mortality (\%) } & Early & $7.52^{\mathrm{ab}}$ & $9.99^{a}$ & $5.83^{b c}$ & $2.68^{c}$ & 0.83 \\
\hline & Mid-term & 0.52 & 0.40 & 1.44 & 1.59 & 0.30 \\
\hline & Late & 3.37 & 4.88 & 3.70 & 4.38 & 0.65 \\
\hline \multicolumn{2}{|l|}{ Pipped-eggs rate (\%) } & 0.52 & 0.40 & 0.43 & 2.05 & 1.31 \\
\hline \multicolumn{2}{|l|}{ Contamination rate (\%) } & 0.90 & ------ & 0.51 & ------- & 1.91 \\
\hline \multicolumn{2}{|l|}{ Culling rate $(\%)$} & 1.95 & 0.52 & 0.94 & 0.55 & 0.41 \\
\hline
\end{tabular}

ab: Means with the different superscript within row are significantly different $(p<0.05)$ 
The average weekly body weight values of the birds derived from the eggs submitted to the different treatments during 5-week feeding period are given in Table 2. From week 3 to the end of the experiment (week 5), males and females were separately weighed. Weekly body weights were different $(p<0.05)$ among treatment groups in all weeks, except for hatching weight. Despite not statistically analyzed, females were heavier than males from week 3 , independently of treatment. In week 5, average body weight of the birds in the control, formaldehyde, garlic-1 and garlic-2 groups were 294.13, 290.56, 288.44, and $304.61 \mathrm{~g}$ respectively $(p<0.05)$.

Wafar et al. (2017), studying the effects of octacosanol extracted from rice bran on quail performance, determined 155.22-186.76 g body weight on day 42, while Yasar \& Gok (2015) obtained154.1-182.6 g on day 35. Guluwa et al.
(2014) reported body weights of 103.81-149.24 gin 35-d-old quails. In the study of Kahksar et al. (2012) on the effects of essential thyme oil dietary supplementation on the performance and blood parameters of Japanese quails, obtained $159 \mathrm{~g}$ body weight in the control group and $169 \mathrm{~g}$ the bird fed thyme essential oil. Alasahan et al. (2016) found an average body weight in 5-week-old quails of 215.77 g, whereas Bonos et al. (2010) reported 172-180.8 g. The body weight values reported in those studies for 5- and 6-week-old quails are lower than those obtained in the present study when quails were still 4 weeks old. In addition, 5-week body weight values were found to be considerably higher than those obtained in the aforementioned studies. This is may be attributed to the fact that the hatching eggs used in the present study derived from quail breeders selected for high body weight.

Table 2 - Weekly body weight (BW) results according to experimental group.

\begin{tabular}{|c|c|c|c|c|c|}
\hline Week & Group & Sex & $\mathrm{N}$ & $\mathrm{BW}(\mathrm{g})$ & Male-female BW average \\
\hline \multirow{4}{*}{ Beginning } & Control & $\mathrm{M}, \mathrm{F}$ & 161 & $8.95 \pm 0.07$ & $8.95 \pm 0.07$ \\
\hline & Formaldehyde & $M, F$ & 144 & $8.87 \pm 0.07$ & $8.87 \pm 0.07$ \\
\hline & Garlic 1 & $M, F$ & 146 & $8.69 \pm 0.07$ & $8.69 \pm 0.07$ \\
\hline & Garlic 2 & $M, F$ & 150 & $8.79 \pm 0.03$ & $8.79 \pm 0.03$ \\
\hline \multirow{4}{*}{1} & Control & $M, F$ & 146 & $38.29 \pm 0.45$ & $38.29 \pm 0.45^{b}$ \\
\hline & Formaldehyde & $M, F$ & 133 & $40.42 \pm 0.44$ & $40.42 \pm 0.44^{a}$ \\
\hline & Garlic 1 & $M, F$ & 134 & $39.65 \pm 0.42$ & $39.65 \pm 0.42^{b}$ \\
\hline & Garlic 2 & $M, F$ & 124 & $38.48 \pm 0.44$ & $38.48 \pm 0.44^{b c}$ \\
\hline \multirow{4}{*}{2} & Control & $M, F$ & 145 & $92.92 \pm 0.88$ & $92.92 \pm 0.88^{a}$ \\
\hline & Formaldehyde & $M, F$ & 132 & $97.53 \pm 0.93$ & $97.53 \pm 0.93^{b}$ \\
\hline & Garlic 1 & $M, F$ & 129 & $94.44 \pm 0.90$ & $94.44 \pm 0.90^{a}$ \\
\hline & Garlic 2 & $M, F$ & 118 & $98.25 \pm 0.88$ & $98.25 \pm 0.88^{a}$ \\
\hline \multirow{7}{*}{3} & Control & $M$ & 72 & $161.56 \pm 2.38$ & \\
\hline & & $\mathrm{F}$ & 73 & $164.98 \pm 2.00$ & $163.45 \pm 1.53^{c}$ \\
\hline & Formaldehyde & M & 61 & $169.88 \pm 2.07$ & \\
\hline & & $\mathrm{F}$ & 67 & $172.14 \pm 2.56$ & $170.89 \pm 1.61^{a}$ \\
\hline & Garlic 1 & M & 70 & $162.84 \pm 2.38$ & \\
\hline & & $\mathrm{F}$ & 57 & $173.96 \pm 1.94$ & $168.60 \pm 1.61^{a b}$ \\
\hline & Garlic 2 & $\begin{array}{c}M \\
F\end{array}$ & $\begin{array}{l}58 \\
59\end{array}$ & $\begin{array}{l}162.39 \pm 2.79 \\
167.70 \pm 2.95\end{array}$ & $164.89 \pm 2.03^{b c}$ \\
\hline \multirow{6}{*}{4} & Control & $\begin{array}{c}M \\
F\end{array}$ & $\begin{array}{l}71 \\
73\end{array}$ & $\begin{array}{l}229.77 \pm 2.51 \\
237.15 \pm 2.24\end{array}$ & $233.77 \pm 1.70^{b}$ \\
\hline & Formaldehyde & $\begin{array}{l}M \\
F\end{array}$ & $\begin{array}{l}61 \\
66\end{array}$ & $\begin{array}{l}234.78 \pm 2.77 \\
241.23 \pm 2.93\end{array}$ & $237.65 \pm 2.03^{a b}$ \\
\hline & Garlic 1 & $\mathrm{M}$ & $\begin{array}{l}00 \\
70\end{array}$ & $227.09 \pm 2.87$ & $231.05 \pm 2.03$ \\
\hline & & $\mathrm{F}$ & 57 & $242.37 \pm 2.64$ & $235.08 \pm 2.05^{b}$ \\
\hline & Garlic 2 & $\mathrm{M}$ & 57 & $236.15 \pm 2.23$ & \\
\hline & & $\mathrm{F}$ & 59 & $250.43 \pm 2.69$ & $242.79 \pm 1.86^{a}$ \\
\hline \multirow{8}{*}{5} & Control & M & 71 & $275.72 \pm 3.12$ & \\
\hline & & $\mathrm{F}$ & 73 & $309.16 \pm 2.93$ & $294.13 \pm 2.59^{b}$ \\
\hline & Formaldehyde & M & 61 & $276.33 \pm 3.13$ & \\
\hline & & $\mathrm{F}$ & 66 & $308.93 \pm 3.73$ & $290.56 \pm 2.84^{b}$ \\
\hline & Garlic 1 & M & 68 & $267.73 \pm 3.47$ & \\
\hline & & $\mathrm{F}$ & 57 & $307.67 \pm 3.92$ & $288.44 \pm 3.25^{b}$ \\
\hline & Garlic 2 & M & 58 & $283.59 \pm 3.16$ & \\
\hline & & $\mathrm{F}$ & 58 & $329.28 \pm 4.43$ & $304.61 \pm 3.50^{a}$ \\
\hline
\end{tabular}

ab: Means in the same column with the different superscriptsin the same week are significantly different $(p<0.05)$. M: male, F: Female 
Independently of experimental group, body weight gain increased up to weeks 3 and 4 and started decreasing after week 4 (Table 3). Şeker et al. (2007) report that weight gain of quails increases until 5 weeks of age, and quickly decreases afterwards. Baylan et al. (2009) reported that the highest body weight gain in quails occurs between 3 and 5 weeks of age. In the present study, body weight gain values of the control, formaldehyde, garlic-1, and garlic-2 groups were 285.18, 281.69, 279.75, and $295.82 \mathrm{~g}$, respectively. Bulus et al. (2013) fed Japanese quails with a commercial poultry feed with two different protein levels during the starter and finisher phases and reported an average body weight gain of $134.24 \mathrm{~g}$ at 5 weeks of age. Devarasetti et al. (2016), evaluating the effects of the dietary supplementation of baker's yeast as a probiotic on the performance of quails, reported that body weight gains during a 0 to 6 -week period of 204.94, 219.96, and 255.95g for quails fed 0, 5, and $10 \%$ yeast, respectively.

Table 3 - Weekly body weight gain(BWG) andfeed intake(FI), cumulativefeed intake(CFI), and feed conversion ratio (FCR), according to treatment group.

\begin{tabular}{|c|c|c|c|c|c|c|}
\hline Week & Group & $\mathrm{N}$ & BWG & $\mathrm{FI}$ & $\mathrm{CFI}$ & FCR \\
\hline \multirow{4}{*}{ Initial } & Control & 161 & ---- & ---- & ---- & ---- \\
\hline & Formaldehyde & 144 & --- & --- & --- & ---- \\
\hline & Garlic 1 & 146 & --- & ---- & ---- & ---- \\
\hline & Garlic 2 & 150 & ---- & ---- & ---- & ---- \\
\hline \multirow{4}{*}{1} & Control & 146 & 29.34 & 47.57 & 47.57 & 1.62 \\
\hline & Formaldehyde & 133 & 31.55 & 48.03 & 48.03 & 1.52 \\
\hline & Garlic 1 & 134 & 30.96 & 44.87 & 44.87 & 1.44 \\
\hline & Garlic 2 & 123 & 29.69 & 50.29 & 50.29 & 1.69 \\
\hline \multirow{4}{*}{2} & Control & 145 & 54.63 & 100.57 & 148.14 & 1.84 \\
\hline & Formaldehyde & 132 & 57.11 & 107.84 & 155.87 & 1.88 \\
\hline & Garlic 1 & 129 & 54.79 & 109.56 & 154.43 & 1.99 \\
\hline & Garlic 2 & 118 & 59.77 & 110.36 & 160.65 & 1.84 \\
\hline \multirow{4}{*}{3} & Control & 145 & 70.53 & 150.35 & 298.49 & 2.13 \\
\hline & Formaldehyde & 128 & 73.36 & 157.77 & 313.64 & 2.15 \\
\hline & Garlic 1 & 127 & 74.16 & 154.85 & 309.28 & 2.08 \\
\hline & Garlic 2 & 117 & 66.64 & 149.79 & 310.44 & 2.24 \\
\hline \multirow{4}{*}{4} & Control & 144 & 70.32 & 207.46 & 505.95 & 2.95 \\
\hline & Formaldehyde & 127 & 66.76 & 219.27 & 532.91 & 3.28 \\
\hline & Garlic 1 & 127 & 66.48 & 212.28 & 521.56 & 3.18 \\
\hline & Garlic 2 & 116 & 77.90 & 219.64 & 530.08 & 2.81 \\
\hline \multirow{4}{*}{5} & Control & 143 & 60.36 & 254.65 & 760.60 & 4.21 \\
\hline & Formaldehyde & 127 & 52.91 & 264.13 & 797.04 & 4.99 \\
\hline & Garlic 1 & 125 & 53.36 & 260.28 & 781.84 & 4.87 \\
\hline & Garlic 2 & 116 & 61.82 & 264.52 & 794.60 & 4.27 \\
\hline
\end{tabular}

ab: Means in the same column with different superscriptsin the same week are significantly different $(p<0.05)$

Cumulative feed intake values at the end of the 5-week period of 760.60,797.04, 781.84, and 794.60g and feed conversion ratios of $4.21,4.99,4.87$, and 4.27 for the control, formaldehyde, garlic-1 and garlic-2 groups, respectively (Table 3 ). Both feed intake and feed conversion ratio were not significantly different ( $p>0.05$ ) among treatment groups. Independently of treatment, FCR increased with age.

The values reported by Baylan et al. (1997) for cumulative feed intake $(674.71 \mathrm{~g})$ and feed conversion ratio (3.32) of 5-week-old quails are lower than those found in the present study. Kahksar et al. (2012), evaluating the effects of the dietary addition of thyme essential oil on the performance of Japanese quails, reported 443 and $458 \mathrm{~g}$ cumulative intake for the control and thyme-fed groups, respectively, which are lower than those found in the present study. On the other hand, the cumulative feed intake results of the present study are lower than those found by Kalio et al. (2016) in 35-d-old Japanese quails, of $951.45 \mathrm{~g}$. The feed conversion ratio values obtained here are consistent with those reported by Wafar et al. (2017), of4.74-5.10 in 42-d-old Japanese quails, and by Cheong et al. (2016), who determined 4.49-5.10 in 5 -week-old quails fed different levels of spirulina.

\section{CONCLUSIONS}

The use of garlic extract, a natural product, for the disinfection of hatching eggs does not have any negative 
The Effects of Using Garlic Extract for Quail Hatching Egg Disinfection on Hatching Results and Performance effects on embryo development, hatching parameters or live performance of quails, and therefore, it may be used as an alternative formaldehyde fumigation.

\section{REFERENCES}

Alasahan S, Copur Akpınar G, Canogullari S, Baylan M.The impact of eggshell colour and spot area in japanese quails: II. slaughtering and carcass characteristics. Revista Brasileira de Zootecnia 2016;45(9):509517.

Al-Homidan AA. Efficacy of using different sources and levels of Allium sativum and Zingiber officinale on broiler Chicks performance. Saudi Journal of Biological Science 2005;12:96-102.

Al-Shammari KIA, Batkowska J, Gryzinska MM. Assessment of ultraviolet light effect in hatching eggs disinfection on hatchability traits of two breeds of quails and chickens. Acta Scientiarum Polonorum, Seria Zootechnica 2015;14(2):33-44.

Ankri S, Mirelman D. Antimicrobial properties of allicin from garlic. Microbes and Infection 1999;1(2):125-9

C\&EN - Chemical and Engineering News. Formaldehyde may face regulation. Chemical Engineering News 1984;62:8.

Ao X, Yoo JS, Lee JH, Jang HD, Wang JP, Zhou TX, et al. Effects of fermented garlic powder on production performance, egg quality, blood profiles and fatty acids composition of egg yolk in laying hens. Australian Journal of Animal Science 2010;23(6):786-791.

Arhienbuwa FE, Adler HE, Wiggins AD. Method of surveillance for bacteria on the eggshell of turkey eggs. Poultry Science 1980;59:28-33.

Astal Z, Younis K. The inhibitory action of aqueous garlic extract on the growth of certain pathogenic bacteria. East \& Central African Journal of Pharmaceutical Sciences 2003;6(1):9-14.

Aygun A, Sert D. Effects of ultrasonic treatment on eggshell microbial activity, hatchability, tibia mineral content, and chick performance in Japanese quail (Coturnix coturnix japonica) eggs. Poultry Science 2012;91(3):732-738

Aygun A, Sert D, Copur G. Effects of propolis on eggshell microbial activity, hatchability, and chick performance in Japanese quail (Coturnix coturnix japonica) eggs. Poultry Science 2012;91:1018-1025.

Aygun A, Sert D. Effects of prestorage application of propolis and storage time on eggshell microbial activity, hatchability, and chick performance in Japanese quail (Coturnix coturnix japonica) eggs. Poultry Science 2013;92(12): 3330-3337.

Baydar H, Sagdic O, Ozkan G, Karadogan T. Antibacterial activity and composition of essential oils from origanum, thymbra and satureja species with commercial importance in Turkey. Elseivier Food Control 2004;15:169-172.

Baylan M, Ayaşan T, Uluocak AN, Okan F. Bıldırcınlarda besi özelliklerinin eşeye ve haftalara göre değişimi. Trakya Bölgesi II. Hayvancılık Sempozyumu; 1997 Oct 9-10; Tekirdağ: Trakya Üniversitesi Tekirdağ Ziraat Fakültesi Zootekni Bölümü, Bildiriler Kitabı; 1997. p.331-334.

Baylan M, Canoğulları S, Şahinler S, Uluocak AN, Çopur G. Effects of divergent selection methods based on body weights of quail on improvement of broiler quail parents. Journal of Animal and Veterinary Advances 2009;8(5):962-970

Bialka KL, Demirci A, Knabel SJ, Patterson PH, Puri VM. Efficacy of electrolyzed oxidizing water for the microbial safety and quality of eggs. Poultry Science 2004;83:2071-2078.
Board, RG. The growth of gram-negative bacteria in the hen's egg. Journal of Applied Bacteriology 1964;27:350-364.

Bonos EM, Christaki EV, Florou-Paneri PC. Performance and carcass characteristics of Japanese quail as affected by sex or mannan oligosaccharides and calcium propionate. South African Journal of Animal Science 2010;40(3):173-184

Bulus ED, Aguda AY, Ezekiel J, Dodo ST, Ibe EA. Growth performance of Japanese quails (Coturnix coturnix japonica) fed two types of commercial broiler diet. Advances in Agriculture, Sciences and Engineering Research 2013;3(10):1227-1234.

Cadirci S. The effect of fumigation regimens on eggshell structure and embryo viability [dissertation]. Glasgow (UK): The University of Glasgow; 1997.

Canogullari S, Baylan M, Erdogan Z, Duzguner V, Kucukgul A. The effects of dietary garlic powder on performance, egg yolk and serum cholesterol concentrations in laying quails. Czech Journal of Animal Science 2010;55(7):286-293.

Cheong DSW, Kasım A, Sazılı AQ, Omar H, Teoh JY. Effect of supplementing spirulina on live performance, carcass composition and meat quality of Japanese Quail. Agricultural Technology and Biological Sciences 2016;13(2):77-84

Choi IH, Park WY, Kim YJ. Effects of dietary garlic powder and $\alpha$-tocopherol supplementation on performance, serum cholesterol levels, and meat quality of chicken. Poulty Science 2010;89:1724-1731.

Chowdhury SR, Chowdhury SD, Smith TK. Effects of dietary garlic on cholesterol metabolism in laying hens. Poultry Science 2002; 81(12):1856-62

Copur G, Arslan M, Baylan M, Canogullari S. Use of allicin as an alternative hatching egg disinfectant versus formaldehyde fumigation in broiler hatching eggs. Biotechnology \& Biotenchnological Equipment 2011;25(3):2494-2498.

Copur G, Arslan M, Duru M, Baylan M, Canogullari S, Aksan E. Use of oregano (Origanum onites L.) essential oil as hatching egg disinfectant, African Journal of Biotechnology 2010;8(17):2531-2538.

Coufal CD, Chavez C, Knape KD, Carey JB. Evaluation of a method of ultraviolet light sanitation of broiler hatching eggs. Poultry Science 2003;82:754-759

Cox NA, Berrang ME, Buhr RJ, Bailey JS. Bactericidal treatment of hatching eggs IV:Hydrogen peroxide applied with vacuum and a surfactant to eliminate salmonella from hatching eggs. Journal of Applied Poultry Research 2000;9:53-534

De Reu KD, Grijspeerdt K, Herman L, Heyndrickx M, Uyttendaele M, Debevere J, et al. The effect of a commercial uv disinfection system on the bacterial load of eggshell eggs. Letters in Applied Microbiology 2006;42(2):144-148.

Debes A, Basyony M. The use of oregano (origanum vulgare I) and ginger (zingiber officinale) oils as alternative hatching egg disinfectant versus formaldhyde fumigation in leghorn and matrouh eggs. Egyptian Poultry Science 2011;31(4):755-765.

Devarasetti AK, Kumar ESA, Ramana KV, Ramsingh L. Supplementation of dietary yeast on body performance in Japanese quails. International Journal of Veterinary Sciences and Animal Husbandry 2016;1(3): 12-14

Elibol O, Uysal A, Ertaş S. Kuluçkalık yumurtalara inkübasyon öncesi farklı konsantrasyon ve sürelerde uygulanan formaldehit fumigasyonunun kuluçka özelliklerine etkisi. Tarım Bilimleri Dergisi 2003;9(1):9-12.

Farbman KS, Barnett ED, Bolduc GR, Klein J. Antibacterial activity of garlic and onions: a historical perspective. Pediatric Infectious Disease Journal $1993 ; 12: 613-614$. 
The Effects of Using Garlic Extract for Quail Hatching Egg Disinfection on Hatching Results and Performance
Gholami-Ahangaran M, Shahzamani S, Yazdkhasti M. Comparison of Virkon $S \circledR$ and Formaldehyde on hatchability and survival rate of chicks in disinfection of fertile eggs. Revue Médecine Vétérinaire 2016;167(12):45-49.

Gordon RF, Tucker JF. The epizootology of Salmonella menston infection of fowls and the effect of feeding poultry food artificially infected with Salmonella. British Poultry Science 1965; 6:251-264.

Guluwa L, Madaki YA, Machido H, Dantayi RJ, Kulokom S. Growth performance and carcass evaluation of quails fed graded levels of water soaked sweet orange peel meal (SOPM). Advances in Life Science and Technology 2014;20: 1-7

Hafez HM, Hauck R. Efficacy of a herbal product against Histomonas meleagridis after. experimental infection of turkey poults. Archives of Animal Nutrition 2006;60(5):436-442.

Hanafy MS, Shalaby SMA, Abd el-Aziz MI, Soliman FA. Effect of garlic on lead contents in chicken tissues. Deutsche Tierarztliche Wochenschrift 1964; 101(4):157-158.

Harry EG. Some observations on the bacterial content of the ovary and oviduct of the fowl. British Poultry Science 1963;4:63-70.

Hrncar C, Prachárová S, Bujko J. The effect of disinfection of hatching eggs on hatchability of oravka chickens. Animal Science and Biotechnologies 2012;45(2):411-414.

Ibrahim, JI, Mansour HD, Abdelrahman, HA Prevalence and inhibition of microbial load on chicken eggs with special references to egg quality and hatchability. American Journal of Animal and Veterinary Sciences 2014;9(4):294-302.

Jakubcova Z, Mareš P, Zeman L, Horký P, Juríková T, Mlček J, et al. Influence of garlic exract on antioxidant status of chicken. Potravinarstvo 2014;8(1):315-320.

Kalio GA, Wariboko ON, Okafor BB. Growth performance and haematological profile of growing japanese quails fed graded levels of azadirachta indica leaf meal. Journal of Animal Science Advances 2016;6(2):1586-1594.

Keita A, Huneau-Salaün A, Guillot A, Galliot P, Tavares M, Puterflam J. A multi-pronged approach to the search for an alternative to formaldehyde as an egg disinfectant without affecting worker health, hatching or broiler production parameters. Poultry Science 2016;95(7):1609-1616.

Khaksar V, Krimpen M, Hashemipour H, Pilevar M. Effects of thyme essential oil on performance, some blood parameters and ıleal microflora of Japanese quail. Journal of Poultry Science 2012; 49:106-110.

Lim KS, You S, An JBK, Kang CW. Effects of dietary garlic powder and copper on cholesterol content and quality characteristics of chicken eggs. Asian-Australasian Journal of Animal Science 2006;19(4):582586.

Makaklı B. Günümüzde şifalı bitkiler. İstanbul: Kipaş Dağııımcılık; 1980.

Olobatoke RY, Mulugeta SD. Effect of dietary garlic powder on layer performance, fecal bacterial load, and egg quality. Poultry Science 2011;90:665-670.

Peinado MJ, Ruiz R, Echávarri A, Rubio LA. Garlic derivative propyl propane thiosulfonate is effective against broiler enteropathogens in vivo. Poultry Science 2012;91:2148-2157

Pienaar ACE, Coetzee L, Bragg RR. A rapid method to determine bacterial contamination on hatching eggs. 2. Correlation of the optical-density measurements after incubation to bacterial counts on hatching eggs. Onderstepoort Journal of Veterinary Research 1995;62:25-33.
Proudfoot FG, Nash DM, Hulan HW. Effects of glutaraldehydesurfactant solution on the hatchability of the hen's egg. Poultry Science 1985; 64:2100-2402.

Raeesi M, Hoseini- Aliabad SA, Roofchaee A, Zare Shahneh A, Pirali S. Effect of periodically use of garlic (allium sativum) powder on performance and carcass characteristics in broiler chickens. World Academy of Science, Engineering and Technology 2010;4:8-21.

Russell SM. The effect of electrolyzed oxidizing water applied using electrostatic spraying on pathogenic and indicator bacteria on the surface of eggs. Poultry Science 2003;82:158-162.

Sacco RE, Renner PA, Nestor KE, Saif YM, Dearth RN. Effect of hatching egg sanitizers on embryonic survival and hatchability of turkey eggs from different lines and on egg eggshell bacterial populations. Poultry Science 1989;68:1179-1184.

Salih BA, Abasiyanik FM. Does regular garlic intake affect the prevalence of Helicobacter pylori in asymptomatic subjects. Saudi Medical Journal 2003;24(10):1152.

Şeker I, Bayraktar M, Kul S, Özmen O. Effect of slaughter age on fattening performance and carcass characterestics of Japanese quail. Journal of Applied Animal Research 2007;31:193-195.

USDA. National poultry improvement plan and auxiliary provisions. Hyattsville: Animal and Plant Health Inspection Service. Veterinary Service; 1985. (Miscellaneous Publication, 91-40).

Varmaghany S, Torshizi MAK, Rahimi S, Lotfollahian H, Hassanzadeh $M$. The effects of increasing levels of dietary garlic bulb on growth performance, systolic blood pressure, hematology and ascites syndrome in broiler chickens. Poultry Science 2015;94:1812-1820.

Wafar RJ, Ojinnaka PE, Tarimbuka LI, Iliya DS, Shehu II. Growth performance, Carcass Characteristics and blood profile of Japanese quails fed dietary octacosanol. MAYFEB Journal of Agricultural Science 2017;1:23-28.

Whistler PE, Sheldon BW. Comparison of ozone and formaldehyde as poultry hatchery disinfectants. Poultry Science 1989;68:1345-1350.

Williams JE, Dillard LH, Hall GO. Penetration of chicken egg shells by members of the Arizona group. Avian Diseases 1968;12:645-649.

Yalcın S, Onbasılar I, Ebru E, Reisliz, Yalcın S. Effect of garlic powder on the performance, egg traits and blood parameters of laying hens. Journal of the Science of Food and Agriculture 2006;86:1336-1339.

Yalıın S, Onbasılar I, Sehu A, Yalıın S. The effects of dietary garlic powder on the performance, egg traits and blood serum cholesterol of laying Quails. Asian-Australasian Journal of Animal Science 2007;20(6): 944947.

Yasar S, Gok MS. Fattening performance of Japanese quails (Coturnix coturnix japonica) fed on diets with high levels of dry fermented wheat, barley and oats grains in whey with citrus pomace. Bulletin UASVM Animal Science and Biotechnologies 2014;71(1):51-62.

Yildirim I, Ozsan M, Yetisir R. The use of oregano (Origanum vulgare L.) essential oil as alternative hatching egg disinfectant versus formaldehyde fumigation in quils (Coturnix coturnix japonica) eggs. Revue Médecine Vétérinaire 2003;154(5):367-370.

Yildirim I, Aygun A, Sert D. Effects of preincubation application of low and high frequency ultrasound on eggshell microbial activity, hatchability, supply organ weights at hatch, and chick performance in Japanese quail (Coturnix coturnix japonica) hatching eggs. Poultry Science 2015;94:1678-1684 